\title{
Sami Torssonen
}

\section{Sellfare: A History of Livestock Welfare Commodification as Governance}

Introduction. The commodification of livestock welfare has recently become a prominent topic of discussion among producers, retailers, nongovernmental organizations, policy makers, and academics. Welfare is increasingly considered "a win-win opportunity for animals, farmers and consumers," as the title of a 2012 conference organized by FAO and the Slow Food organization proclaims, since "farming practices that take into account high animal welfare standards guarantee greater productivity, better quality, more food safety and added value for farmers" (The Food and Agriculture Organization of the United Nations). Commodification is not expected to happen by itself, however. The European Union's 2012 animal welfare strategy, published at an event titled "Empowering consumers and creating market opportunities for animal welfare" (European Commission, "Animal Welfare"), propounds active "valorization of welfare standards as a means to enhance competitiveness of EU food industry" and attempts to seize "every opportunity to express in economic terms the value added by animal welfare policy" (European Commission, "Communication From the Commission" 4, 7).

The texts quoted above, and many others like them, are part of a process through which the production and sale of livestock welfare has recently become feasible. Operational welfare measurement systems have been developed for use in livestock production facilities (e.g., Blokhuis). A plethora of assessment, certification, marketing, and education schemes have been introduced (Schmid and Kilchsperger). Studies on the welfare market are proliferating (Norwood and Lusk 302-305). Together these developments enable the production of livestock welfare for sale, i.e. its production as a commodity (Marx, Capital 125-177).

This article studies the emergence of commodified livestock welfare. It shows that livestock welfare commodification has never been an exclusively economic phenomenon. Rather, it has been steered by attempts at purposive social coordination, here called governance. The article coins the notion "sellfare" to describe this complex of livestock welfare commodification as governance. 
The article takes a historical approach to sellfare. It outlines a chronological history of welfare governance and welfare commodification. In so doing, it traces sellfare's contemporary aspects back to their circumstances of emergence. Sellfare thus appears as a complex of historical "layers," each of which has accumulated over a different time period. The article shows that many of sellfare's layers are quite old, but that they have only come together in the 1990s as commodified welfare.

The word "sellfare" itself combines three historical layers, each of which the article discusses in turn. The simplest and most long-standing of sellfare's layers is "fare," as in "how do you fare?" or "fare well." Fare refers to generic human concern for non-human thriving. The article begins by tracing such concern back to a contradiction within domestication. It shows why humans and "their" animals have never been able to journey (Old English faran) together without trouble.

The second historical layer contained within sellfare is "welfare." In this article, welfare refers to the well-being of industrially-produced non-human subjects as governed by a state-civil society dynamic. The roots of welfare lie in 19th century liberal fare governance. Welfare was only perfected, however, in the scientific regulation of the 20th century livestock factory. Up to the 1980s, welfare was a largely legislative instrument that worked by shielding livestock from some of the effects of their commodity status. The article outlines the emergence and development of welfare in sections four, five, and six.

The "sell" of sellfare, finally, connotes the addition of commodification as an instrument of welfare governance since the 1990s. For the first time in history, sellfare enables the mass production of scientifically-measured thriving for the purpose of selling it. Contrary to previous welfare governance, livestock suffering becomes a resource rather than a problem: public concern for livestock thriving now enables the sale of scientifically-certified welfare products. The article outlines the current form of sellfare in section seven. It concludes by reflecting on sellfare's future development.

To ground the analysis, the next section situates the article in previous literature. It reviews recent discussions on ethical consumption, welfare governance, and welfare commodification. Afterwards, the discussion turns to the article's central theoretical concepts, i.e. "commodification," "relation," "contradiction," and "governance," and the data used.

Humanimalia: a journal of human/animal interface studies

Volume 7, Number 1 (Fall 2015) 
Approach and literature. During the past two decades, several bodies of social-science literature have emerged around topics that touch on livestock welfare commodification. The largest of these discusses what might be called ethical consumption (see Vitell; Röcklinsberg and Sandin). The ethical-consumption literature emphasizes themes such as performed identities (Schaefer and Crane), followed frames (Bateman, Fraedrich, and Iyer), consumption as voting (Shaw, Newholm, and Dickinson), limited possibilities (Barnett et al.), ideology (Žižek, First As Tragedy 51-69), and expressed preferences and conquered market failures (Norwood and Lusk). This literature is, however, by itself insufficient to account for sellfare, which also concerns production and governance.

More promising are inquiries into various stakeholders' attempts at livestock welfare governance. These include analyses of welfare in food policy (Bennett), industry responses to welfare demands (Adams), welfare in quality assessment and food chain transparency (Blokhuis et al.), welfare as a bridge between science and society (Blokhuis), welfare as a perpetuator of species privilege (Cole), attempts to construct an international trade regime for welfare (Hobbs et al.), and possible futures of welfare governance (P. Ingenbleek et al.). Freidberg, in particular, describes an "ethical complex" of nongovernmental organizations, media exposés, and retailers that governs the agro-food supply chain. These treatments do not discuss commodification as a form of governance.

The analyses closest to this article concern livestock welfare "commodification," "marketization," "economization," or "market policy." These works emphasize the factors that render welfare producible and salable at various points in the commodity chain. Buller and Roe, for instance, periodize the historical development of the British poultry market from marketization in the 1980s through differentiation, EU-imposed labeling, and finally choice editing by retailers. Buller and Cesar analyze the discourses of eating welfare produced by French food marketers. Miele and Lever highlight the role of welfare science in constructing a "civilized" market. A number of authors have also given political-economic rationalizations for state intervention in the welfare market (e.g., Harvey and Hubbard; Ingenbleek et al.). The existing analyses of commodification lack, however, the long historical perspective that is provided here.

This article adopts a Marxian understanding of commodification as the process through which goods become producible for sale. Commodities are defined as useful products of quantities of average labor time that exchange with each other in ratios that are expressed by their prices (Marx, Capital 125-177). Commodification thus requires that livestock welfare 
become useful, producible, and salable. This is not a trivial requirement. Welfare commodification has many historical preconditions, including public concern, government intervention, scientific measurement, and certification. This article focuses mainly on the emergence of such conjunctural preconditions of welfare production, and less on systemic factors. In other words, the article belongs with the discipline of history rather than that of economics despite its focus on commodification.

Two theoretical concepts of Marxian historiography are of particular relevance to the discussion that follows. First, phenomena are here conceived as layered accumulations of historic relations (Marx, Grundrisse 105-106). The article shows how the relations that now underlie sellfare have emerged and developed. Second, relations may be contradictory insofar as their relata depend upon each other but also negate each other, such as with wage labor and capital. As contradictions build up, a phenomenon may become torn by multiple axes of contradiction that are internal to it and affect its development (Althusser 87-128). The article teases out five such relational contradictions of sellfare and its aspects.

In addition to Marxian vocabulary, the article draws on governance studies. "Governance" is here understood to mean purposive societal coordination through means such as hierarchies, markets, and networks (cf. Bevir 162-164). The concept can, furthermore, be disaggregated into historical periods or "hegemonic concepts of control" (Overbeek 7). One of these is neoliberal governance that, since its emergence in the 1970s (Harvey 51-108), has put a particular emphasis on utilizing hierarchies and networks to impose market-like relations as solutions to perceived problems. Sellfare is an effect of neoliberal governance that makes livestock welfare producible for sale on the market as a response to public concern over livestock welfare. It is thus not reducible to direct economic pressures, but also presupposes attempts at conscious regulation by non-market civil-societal and state actors.

The analysis is based on readings of secondary scholarship in English and German. In addition, less-researched recent developments are analyzed through publicly available documents on welfare commodification. This approach has several limits. Developments outside old core capitalist countries cannot be properly accounted for. The history presented here is also what some would call "teleological" (Woods, "From Cruelty to Welfare" 166) or "presentist" (Seidman), but what could equally well be called "reading the past from the present"s point of view." The article does not account for what could have been, what is no more, or what is dormant or minor.

Humanimalia: a journal of human/animal interface studies

Volume 7, Number 1 (Fall 2015) 
A corollary limitation follows from the fact that the article is, in the words of Deleuze and Guattari, a taproot rather than a rhizome (5). Sellfare is the shaft at the center of the inquiry, and everything else is oriented towards it. Despite this, capital is not construed as a transcendent subject of history. The narrative here is more akin to a history of beginnings, in which phenomena and contradictions appear for whatever reasons (which are accounted for in a limited way) and then coalesce into capital and governance. It is only after many coincidences and co-options that sellfare emerges from a constellation of interspecies sensitivity, governance, science, and quality policy.

The Animal Connection and Domestication. The profound societal and individual significance of human relations with other animal species is well known. Livestock systems occupy approximately 30 percent of the world's ice-free terrestrial surface and boast an economic value in the trillions, a nutritional value in the tens of percentage points, a yearly death toll in the tens of billions, and substantial consequences for the environment and public health (Thornton; Steinfeld et al.). Companionship relations between humans and non-human animals are widespread, profoundly affecting the health, education, and social lives of those participating in them (Friedmann and Son). Large industries operate in fields like companion animal retail, grooming, health, nutrition, and insurance (e.g., American Pet Products Association). Non-human animals make prominent appearances in childrens' earliest vocabularies (P. C. Lee 194-195), religious texts (Bryant), metaphors (Talebinejad and Dastjerdi), and Rorschach test ink stains (Mason). Animal use has been subject to regulation in contexts as different as ancient Egypt, imperial Rome, and the European Union (Clutton-Brock; Li).

If widespread and active nurturing relations between humans and non-human domesticated animals did not exist, sellfare would not be possible. The existence of such relations is, however, far from self-evident. Paleoanthropologist Pat Shipman's search of the scientific literature only turned up one report of wild non-human primates adopting and nurturing individuals of another species (Shipman, "The Animal Connection and Human Evolution" 4). If other primates do not engage in interspecies domestication, why do humans? Shipman presents a coevolutionary animal connection hypothesis that, though fairly recent, partial, and somewhat controversial (7-14), is supported by a great deal of evidence from multiple disciplines (Hodgson and Helvenston; Helvenston and Hodgson; Budiansky 33-41; Zeuner 36-46). Relative to similar work that focuses less on the species relation (Mithen 256-259), Shipman's account is also well equipped to explain why animal suffering recurs as a societal problem and why humans often desire non-human animal thriving. 
Shipman argues, based mainly on archaeological and fossil evidence, that the animal connection is a product of a long coevolutionary process in which humans and nonhuman animals have become increasingly entwined with one another (Shipman, "The Animal Connection and Human Evolution"). First, approximately 2.6 million years ago (cf. Domínguez-Rodrigo, Pickering, and Bunn), the utilization of stone tools began to move early members of the genus Homo into a predatory ecological niche. Prey- and predator-related knowledge started to become an adaptive advantage to early humans.

Second, beginning approximately 200,000 years ago, the importance of symbolic information, ritual, and transgenerational knowledge transfer as organizers of early human behavior started to grow. Much of the evidence of this development, such as ritual skulls, is non-figurative and thus difficult to interpret in terms of species relations. The content of figurative prehistoric art is telling, however: non-human animal themes are overwhelmingly common, whereas other potential topics such as humans, tools, landscapes, and plants are rare. Shipman interprets this as an indication of the importance of the storage of animal-related knowledge in the evolution of symbolic communication.

Third, beginning perhaps as early as over 32,000 years ago, humans domesticated dogs and then, beginning approximately 12,000-10,000 years ago, several other non-human animal species (cf. Larson et al.). Shipman reads domestication as an extension of previously evolved affinities and accumulated knowledge: the link between human and non-human animals was now sufficient to take the animal connection to a new level. She characterizes the process of animal domestication, as opposed to plant domestication, as follows:

Because we have the potential to communicate much more directly with animals than with plants, the process of domesticating an animal is much more intimate, personal, and psychologically powerful. I suggest that the process of domesticating an animal is basically the process of creating a genetically encoded potential for a mutual language or communication system, based on a set of shared values. (Shipman, The Animal Connection 197)

According to Zeder (239-50), the domestication process of different non-human animal species probably took various shapes: some scavenged their way into human society, others turned from wild prey into managed herds, and some were purposefully

Humanimalia: a journal of human/animal interface studies

Volume 7, Number 1 (Fall 2015) 
adopted by humans. All of the non-human animals that ended up domesticated were, however, to some extent pre-adaptively compatible with human society in terms such as social structure, sexuality, and dietary propensities. There were often adaptive benefits to domestication in forms such as biomass provision and conversion, surplus storage, security, and labor. Domesticated non-humans were also protected from extinction, which was the fate of many of the species on which early humans preyed (Barnosky). By 2500 BCE, all of the most important contemporary domestic species were found in some societies (Clutton-Brock 77). Earlier species boundary practices such as predation, spiritual reverence, and artistic use were complemented by new practices of caring, breeding, and production.

The evolutionary trajectories of all of the involved species were affected by the process of domestication. Domesticated animals came under constant selective pressure from humans, whereas humans were selected for traits that facilitated dealings with domesticates and their products. As a consequence, domestic animals and humans grew increasingly dependent on each other. Contemporary domestic breeds often retain juvenile characteristics of their species to adulthood exhibiting, among other traits, pronounced gregariousness, submissiveness, and non-aggressiveness, as well as reductions in wariness, response to stimuli, brain size, and capacity for certain kinds of problem-solving (Smith and Litchfield; Gepts et al. 232-239). The bodies, minds, and cultures of humans have also become further attuned to domestic breeds' products, diseases, communication, emotions, and behavior ( $\mathrm{O}^{\prime}$ Brien and Laland). Despite these adjustments, problems such as zoonotic diseases, dietary drawbacks (Cordain), and mutual violence have continuously plagued the species boundary of humans and domesticates.

Shipman's animal connection hypothesis describes the emergence and persistence of the reciprocal conditionality of humans and domesticates. This societal and bodily connection emerged together with a degree of mutual intersubjectivity. Without this intimate connection there could be no sellfare. The existence of sellfare could even be considered as indirect abductive evidence for Shipman's hypothesis.

Shipman's hypothesis has, however, a second, equally important implication for an analysis of sellfare. The animal connection arguably internalizes a contradiction between sensitivity and instrumentality. On the one hand, the connection evolved out of (and into) a need for mutual understanding, bodily dependence, and jointly structured social relations. On the other hand, it evolved out of (and into) the often instrumental 
and inherently asymmetrical relations between predator/prey, domesticator/ domesticated, and labor/means of production. In some ways, human and non-human domesticates are of the same whole; in other ways, their relations are permeated by violent enactment of difference. Human recognition of non-human suffering is a corollary of abuse, as Anna Williams has argued.

The contradiction internal to the animal connection is arguably the main reason why non-human thriving in the face of human usage has engendered concern throughout written history (Preece). This old, generic form of human concern for non-human thriving is here called "fare" for short (cf. Buller and Cesar). Generic fare only exists, however, in historically specific relations. As the next section shows, for example, fare and its governance were altogether different in the 18th and 19th centuries than they are today.

The 18th and 19th Centuries: the Emergence of Liberal Fare Governance. Although the animal connection and its regulation are truly ancient, sellfare is more specific than any animal connection and any regulation. Sellfare consists in entities such as states and civil-societal actors publicly valuing and manipulating the thriving of a population of animals. The preconditions for this liberal fare governance layer of sellfare first emerged during the 18th and 19th centuries, when fare became part of a regulatory process of public debate and governance. This section describes the emergence of the mediatized state-civil society dialectic of liberal fare governance, presents an integrative interpretation of its conditions of possibility, and discusses its relationship with contemporary sellfare.

The analysis pulls together three explanatory strands from the literature on 18th- and 19th-century fare governance. First, what could be called the humanitarian strand concerns changes in the emotional and moral aspects of the animal connection. Second, the governance strand focuses on the changing role of the animal connection in societal coordination. Third, the modernism strand emphasizes human perceptions concerning, and capacities for, rapidly manipulating themselves and their environment.

The backdrop of liberal fare governance is formed by the process of capitalist modernization that culminated in the 18th and 19th centuries. This process transformed the relationships among the public sphere, the state, and the market in parts of Europe and its imperial sphere (Habermas). Technological developments in the relations and forces of production instilled confidence in the human capacity to intervene in nonhuman and human constellations. Contractual relations and notions of far-reaching

Humanimalia: a journal of human/animal interface studies

Volume 7, Number 1 (Fall 2015) 
causal culpability proliferated, implying a heightened sense of moral responsibility (Haskell, "Capitalism and the Origins of the Humanitarian Sensibility, Part 1"; Haskell, "Capitalism and the Origins of the Humanitarian Sensibility, Part 2"). Science increasingly emphasized the unity of life, and humans were either demoted to animals or glorified with characteristically human traits (Franklin 25-26). Morals, knowledge, and mettle came together at the elite-exclusive, bourgeois public sphere of newspapers, salons, parliaments, and societies (Fraser, "Rethinking the Public Sphere"). The ills spewed forth by the "satanic mills" (Polanyi 41) of capitalism came to be governed through a mediatized process of civil society-state interactions. This process is taken here to be the defining characteristic of liberal governance.

Non-human animals were embroiled in the metamorphosis of society that modernization entailed. Beginning in the 17th century, animals were increasingly produced for sale as commodities, or "live stock" (Hribal 438). Concern for them was famously mediatized in William Hogarth's mid-18th century commercial pamphlets that denounced the horrors and moral consequences of animal cruelty (Kalof 124-164), proffering the commonplace modern depiction of animals as the helpless objects of human gaze and depredations. Practices changed alongside representations: pets became prevalent conduits of demonstrative consumption and class affiliation (Brantz 78-79), rendering many humans subject to the affectations of idle non-humans. The harsh lives of commodified animals at the hands of their working-class handlers remained visible, however, in cattle drives, traffic, and print.

The 19th century saw the creation of societies that attracted influential members with words like vegetarian, vivisection, Tierquälerei [animal abuse], and protetrice [protection] (Guither 1-5; Zerbel 1-82; Kete, "Animals and Human Empire" 3). These sought publicity, lobbied for legislation, and sometimes also enforced regulation that the police and magistrates were unable or unwilling to implement (Favre and Tsang). National animal laws increased in number, regulating behaviors such as "publicly or scandalously torturing animals" (Second German Reich, 1871) and "shameful, indecent treatment causing scandal in a public place" (The Russian Empire, 1864) (HardouinFugier 176). The property status of non-human animals was universalized, and practices of legally punishing animals disappeared from Europe and the U.S. by the end of the 19th century (Ritvo 1-5; Legge and Brooman 37).

The notion of public cruelty was central to early liberal fare governance. An important reason for this is to be found in old elite anxieties that were now increasingly targeting 
the proletariat (Kelch, "A Short History of (Mostly) Western Animal Law: Part 1"; Kelch, "A Short History of (Mostly) Western Animal Law: Part II"): Witnessing and partaking in cruelty was thought to have a dangerous effect on the working class (Crossley 35), that beastly Other of the composed modern gentlefolk. Early British animal protectionists, for example, took themselves to be in the business of the "suppress[ion] of dangerous elements of human society" (Kete, "Animals and Human Empire" 2). Influential social reformer Jeremy Bentham argued that "habits of cruelty" and "antisocial propensities" ought to be "repressed" by only allowing the infliction of non-human suffering on respectable grounds (which his utilitarian theory supplied) (Bentham). In France, the proponents of the 1850 anti-cruelty Grammont Law successfully appealed to the elites' fresh fear of the underclass after the uprisings of 1848 (Kete, The Beast in the Boudoir 4-7).

The practical implementation of 18th- and 19th-century fare governance included statesponsored children's anti-cruelty education in France (Stock-Morton 184), activists patrolling the streets as law enforcers in the U.S. (Favre and Tsang 15-17), and the military suppression of cruel entertainment in Britain (Turner 138-139). Unsightly and unclean slaughter was increasingly concentrated within large, municipal compounds that were hidden away from urban centers (A. J. Fitzgerald). A similar process was underway for animal markets by mid-19th century (Philo 666-670). The livestock system was being civilized (cf. Tester 66).

The scope of fare governance expanded towards the end of the 19th century. Steampowered animal transport grew explosively and was governed, in some countries, for both sanitary and sentimental reasons (Woods, "From Cruelty to Welfare" 15; Council of Europe Publishing 177-178). Regulation continued on slaughterhouses, the conveyor belts of which reputedly inspired Ford Motor Company employees to perfect the iconic auto assembly line (P. Y. Lee; Horowitz 37). The scientific clout of animal experimenters continued to balloon, and anti-vivisectionists achieved their first legislative victories. In some cases, the opponents of vivisection allied with anti-positivist, aristocratic, and ecclesiastical elites that resisted the increasing authority of the empirical sciences (Bromander); in other cases, with socialists and feminists (Lansbury). Value and other forms of power flowed ever faster through an ever larger number of non-human bodies, channeled by the criticism that was often integral to them.

In sum, the 19th century saw the emergence of a crucial aspect of sellfare: the governance of fare within a mediatized state-civil society dialectic. Scandalous public exposés and various forms of fare intervention came to complement each other. Liberal

Humanimalia: a journal of human/animal interface studies

Volume 7, Number 1 (Fall 2015) 
fare governance also began to subtly change the motivation of animal regulation. It increasingly treated animals as subjects whose sentiments were valuable as such, yet simultaneously used them to affect human populations. The contradiction between non-human animals as a means and object of liberal fare governance emerged. This contradiction is often mistaken for straightforward benevolence, such as when Kelch argues that modern law "protected animals for their own sakes" ("A Short History of (Mostly) Western Animal Law: Part II" 3) as opposed to older religious and economic reasons. Such formulations overemphasize the degree to which non-human animals have ever been the sole object of liberal fare governance.

At the end of the 19th century, a number of 21st century sellfare's aspects were still missing. The mechanized, capital-intensive, cramped livestock rearing factory was absent, although branches of livestock production did increase their productivity substantially (Federico 71). One of the most important objects and contexts of today's welfare governance and sellfare was thus lacking. Governance rarely concerned animal husbandry, rather focusing on transport, slaughter, and entertainment.

Animal thriving was also not reliably measurable. Although scientific interest and knowledge concerning animal emotions and behavior did emerge particularly towards the end of the century (e.g., Darwin), these were not yet institutionalized as disciplines. Scientists working with living and healthy animals were a minority compared to those using dead or dying ones (Burkhardt 1-126). Laboratory environments for studying and manipulating animal behavior and emotion were nearly non-existent (cf. Gray).

Perhaps most importantly, however, the governance device of animal "welfare" itself was absent. The first echoes of welfare governance could certainly be heard in notions such as "happiness" and "suffering," but it was not possible to operationalize these existing conceptual tools for the manipulation of animal thriving in production. Although some socialists and feminists began to include non-human animals in their demands (Kean), the emblematic Wohlfahrtsstaat [welfare state] of late 19th century Germany was for humans only (Petersen and Petersen).

It would be overly bold to claim that sellfare was impossible at the turn of the century, but the requisite technoscience, governance devices, and production conditions were nonetheless still largely absent. To produce livestock welfare for sale would have been excessively difficult. To encourage such production through policy was inconceivable.

\footnotetext{
Sami Torssonen - "Sellfare: A History of Livestock Welfare Commodification as Governance"
} 
Many phenomena that are important to contemporary sellfare only emerged or consolidated during the 20th century.

The Early 20th Century: Livestock Factories and Welfare Governance. Systems for raising substantial numbers of livestock in cramped conditions already existed in the 19th century. One might cite, for example, late 19th century urban dairies (Woods, "From Cruelty to Welfare" 17), large pig sties (Malcolmson and Mastoris 72-87), and feedlots (Cronon 223-224) as such. On the whole, however, various types of outdoor production and relatively small-scale indoor systems dominated livestock husbandry. It is difficult to pin down why this began to change precisely when it did, in the early 20th century. A general causal analysis of the industrialization of livestock husbandry should certainly mention late 19th century technological developments like fermented silage fodder becoming common (Wilkinson, Bolsen, and Lin) and easing seasonal feed availability variations (Federico 10), the growing viability of refrigerated railroad cars for meat transport (White), and the propagation of agricultural economics, education, and statistics (Runge). Towards the end of the 19th century, increasing affluence among parts of the world's population resulted in the demand for livestock products growing faster than supply (Federico 26-28). The vertical integration of farming increased and lobbyists consolidated (Franklin 130-135). In some cases, such as the agro-industrial revolution of the U.S. Midwest, these factors came together with astonishing consequences (Page and Walker).

Regardless of the specific etiology one opts for, it is beyond doubt that in the first half of the 20th century, new kinds of livestock production systems emerged from the broader process of fertilizer-, combustion-, credit-, and modernism-inflamed agricultural industrialization (D. Fitzgerald). The novel systems kept animals at increasing densities, were increasingly mechanized, specialized, capital-intensive, or indoors, and competed on an equal footing with more extensive systems. It was only in the second half of the 20th century, however, that various kinds of livestock factories began definitively to eclipse other production systems (Norwood and Lusk 42-43; Blokhuis 19-26). Total agricultural workforces plummeted by up to 80 percent between 1938 and 2000 in Western Europe, while fixed capital stocks remained stable or expanded (Federico 4264).

The spread of livestock factories exacerbated the contradiction that was already inherent in animals as commodities (Gunderson, "From Cattle to Capital" 267). An exploding number of affective beings were now reduced to commodities and hidden from the consumers of their flesh, deepening the dialectic of alienation and exposé that

Humanimalia: a journal of human/animal interface studies

Volume 7, Number 1 (Fall 2015) 
had begun in the 18th century. The ascendancy of livestock factories was sealed by antibiotics and interventionist state policies that emphasized food quantity and structural change in agriculture (Winter, Fry, and Carruthers 312). The subsumption of animals into commodities was far from perfect, however, and production systems varied with region and species.

From the start, some proponents of livestock factories argued that intensive indoor systems in fact benefited animals by protecting them (Woods, "Rethinking the History of Modern Agriculture" 174-176). Such claims were forcefully challenged with the onset of the tumultuous 1960s. Books like Silent Spring (1962) in the U.S. and Animal Machines (1964) in Britain sparked controversy around the moral, ecological, and societal consequences of intensive livestock production (Carson; Harrison, Carson, and Dawkins). These were soon translated into numerous languages. Livestock factories increasingly transitioned from the producer's private sphere to the sphere of public concern. As a British government official noted in 1964, "a sort of Factories Act for animals" seemed worth considering (quoted in Woods, "Rethinking the History of Modern Agriculture" 18).

It is in this environment that livestock welfare governance began to consolidate in postwar Britain, from whence it gradually spread across the Anglophone hegemony. According to Woods, references to livestock "welfare" surfaced in British debate during the 1950s (Woods, "From Cruelty to Welfare" 15-16). At this point, "welfare" still connoted livestock thriving in a generic and non-specific sense. A specific meaning only developed after the British Ministry of Agriculture, Fisheries and Food mandated a group of scientific experts "to examine the conditions in which livestock are kept under systems of intensive husbandry and to advise whether standards ought to be set in the interests of their welfare, and if so what they should be" (Brambell 1).

This so-called Brambell committee's influential 1965 report, in some ways reminiscent of factory inspectors' reports from a hundred years earlier, embraced an understanding of welfare as "both the physical and mental wellbeing of the animal." The welfare status of an animal, it argued, could be known through "scientific evidence available concerning the feelings of animals that can be derived from their structure and functions and also from their behavior." The rapporteurs considered welfare compatible with intensive production and even useful to improving productivity (Brambell 9, 63).

\footnotetext{
Sami Torssonen - "Sellfare: A History of Livestock Welfare Commodification as Governance"
} 
Livestock welfare passed into British law in 1968, and much of the Ministry's policy was rebranded under the new moniker (Woods, "From Cruelty to Welfare" 18-19). That same year, the European Convention for the Protection of Animals During International Transport was opened for ratification carrying numerous references to "welfare" (The Council of Europe). During the treaty process, "welfare" was translated verbatim into the languages of the participating nations. Forms such as "Wohlbefinden" [wellbeing], "benessere" [wellbeing], and "gerove" [welfare] were given precedence over previous vocabularies such as the German "artgerecht" [species-appropriate].

Woods gives a number of possible reasons for why "welfare" was adopted in British livestock legislation (Woods, "From Cruelty to Welfare" 18-19), some of which are also applicable to welfare's spread to other national contexts. The reasons can be combined and reformulated into the following three items: First, it would have been controversial for the government to imply that "cruelty" or "suffering" existed in livestock factories. Second, "welfare" evoked the condescending Christian sensibility of caritas [charity], but also suggested a connection with the fashionable welfare state. Third, cruelty policy was traditionally the remit of the Home Office, which is why Agriculture, Fisheries and Food was eager to construct itself a new domain in welfare policy.

Woods' account (Woods, "From Cruelty to Welfare" 14) consciously omits one very important reason for welfare legislation: "Animal welfare" had the benefit of being previously familiar from the rhetoric and research of the animal experimentation lobby, such as the Universities Federation for Animal Welfare (founded in 1926 as the University of London Animal Welfare Society) and the Animal Welfare Institute (founded in 1951 in the U.S.). Welfare had also made a legislative appearance in 1966 in the U.S. when a Laboratory Animal Welfare Act had been adopted after a media scandal around animal research (Adams and Larson).

In sum, the early 20th century saw the emergence of two important aspects of sellfare: livestock factories and scientific livestock welfare governance. Two other aspects were still missing in the 1960s, however. First, animal welfare science consolidated largely after scientific welfare governance. Animal welfare was not widely accepted as a scientific concept at the time of the Brambell committee (Broom, "A History of Animal Welfare Science" 124), and little academic infrastructure existed for it. Although animal behavior had become a respectable and feasible object of science since the emergence of ethology and comparative psychology in the first half of the century (Burkhardt), these disciplines were dominated by approaches that were strongly skeptical of non-human mentation (Rollin) and thus rendered questions concerning welfare difficult to answer.

Humanimalia: a journal of human/animal interface studies

Volume 7, Number 1 (Fall 2015) 
Second, the notion of scientific livestock welfare as a product quality attribute was still inconceivable. Welfare as quality only became intelligible as a result of a broader societal transformation that began after the 1960s. The last part of the article discusses the way in which these two developments, animal welfare science and welfare quality, emerged.

The Late 20th Century: Welfare Science and Quality. As early as 1947, a laboratory animal handbook of the Universities Federation for Animal Welfare promoted a "realistically humane policy based on objective fact" (quoted in Haynes 8) that would draw on research into non-human animals' contentment and pain. At the time, however, such knowledge was virtually non-existent. The Federation began sponsoring research for the benefit of laboratory animals and sound experimental design in the 1950s (Kirk 250-252). Agricultural science departments also began using the influx of post-war productivist policy funds to study the associations of livestock fare and productivity (e.g., Sandilands). Developments of this kind explain why, when ethologist W.H. Thorpe of the aforementioned Brambell committee reported to the British government in 1965, he already had a literature to draw on, even if this was not a welfare science literature as such.

Scientific attention truly turned towards animal welfare in the 1970s amidst growing public concern. Rigorous definitions, valid indicators, telling indices, and robust causal relations were constructed to ground concepts such as those mentioned by Thorpe (e.g., Duncan and Wood-Gush). During the 1980s, something like a disciplinary orientation was gathered under the notion of measurable welfare (Dawkins; Blackshaw; Broom, "Animal Welfare: Concepts and Measurement"). This was followed by rapid increases in publications and institutionalization in the 1990s (Lawrence 5-8). The scientific literacy of stockpeople, among other characteristics, came to be seen as an important guarantor of the welfare and productivity of intensively-produced livestock (Hemsworth and Coleman vii-viii).

The consolidation of welfare science rendered it, as Alistair Lawrence describes the development of his discipline, less "curiosity driven" and more "policy driven," and hence perhaps more "efficient" at promoting welfare (Lawrence 4). One reason for this was probably that welfare science was directly funded and steered by policy drivers. In its second Framework Programme between 1979 and 1983, the European Communities in particular emerged as one of the most important supporters of welfare science. An EC Commission report from 1986 rationalized the funding as follows: 
The pressures of the market-place have resulted in most animal production systems becoming more intensive in an effort to hold products at price levels acceptable to consumers, while, on the other hand, public opinion pressure (not always well informed), which is against certain aspects of modern systems, has been building up. Scientific answers are needed to help avoid the impasse of these two pressures meeting head on. (Commission of the European Communities, Coordinated Agricultural Research - A Record of Achievements 28)

As welfare science entwined with policy, it was also inflected by the factories it was tasked with reforming. Husbandry systems and industrial practices, such as debeaking or tail docking, became a common starting point for welfare research (Cunningham; Stookey and Goonewardene). Welfare science became a component in what could be called protectionist scientific welfare governance: A loosely science-based, largely legislative form of governance that utilized subsidies and restrictions to govern massproduced animals so as to manage the reduction imposed upon them. Words like "Schutz" [protection], "skydd" [protection], and "suojelu" [protection] commonly replaced or accompanied welfare vocabularies under variants of such governance (EU Enforcement Network for Animal Welfare Lawyers and Commissioners).

Even as protectionist welfare governance was solidifying, however, some of its foundations were being undermined by the very circuit of value it was structured around. The relatively unfettered governments of the post-war accumulation regime were being restrained by liberalization, with capital picking up speed, covering ground, and coercing into competition. Butter mountains were growing as symbols of the inefficiencies of state intervention under fluctuating markets. State-produced public goods were appearing increasingly bland and uniform in comparison to private production, especially as firms were pushed towards product differentiation due to the saturation of markets for mass-produced goods (Streeck). Quality management systems spread copiously (e.g., Kelemen) from their seedbed in warfare and manufacturing. Post-modern citizens were being encouraged to take responsibility for themselves in the spirit of self-service democracy (Eriksson and Vogt).

Protectionist livestock factory legislation was slowly complemented by minor forms of market-based governance. Livestock product quality certification systems, such as the French government's Label Rouge [red label] (1960s) and the private Scharrel [free range] (1970s) in the Netherlands, acted as explicit higher-standards alternatives to livestock

Humanimalia: a journal of human/animal interface studies

Volume 7, Number 1 (Fall 2015) 
factories and legislation (Schmid and Kilchsperger 233-240). Although some of these early initiatives coupled commercial benefits with various notions of fare, their advantages were mainly identified with increased productivity and tastier or safer products (e.g., Bieleman 279; Fanatico, Born, and Conner). Welfare was not yet for sale as such. Welfare science was not yet capable of robustly abstracting livestock welfare into a single index in the mid-1980s (Blackshaw).

The 1990s and Onwards: The Birth of Sellfare. By the mid-1990s, European livestock production and its governance had changed visibly from the post-war situation, and the outlines of sellfare were readily discernible. "Mad cow disease" was endemic in the media. Deteriorating consumer perceptions of the safety and quality of industriallyproduced food (e.g., Alvensleben), together with the associated fall in food prices, were driving demand for standards. Agricultural certification systems were multiplying rapidly (Areté 4), and welfare had become central to several of these (e.g., Neuland). Liberalization was incentivizing the creation of new market-based and "multifunctional" policy instruments such as the organic system (Huylenbroeck and Durand 1-83; Vogel). Private and state actors were building new consumption spaces alongside and inside productivist intensification (Potter and Tilzey 584). The EU's agricultural policy focus was on quality over quantity (Commission of the European Communities, COM [85] 333 Final, Perspectives for the Common Agricultural Policy [Communication of the Commission to the Council and the Parliament]), and research funding was being directed towards discovering how to best produce welfare for sale (European Commission, Ethical, Legal and Socio-Economic Aspects of Agriculture, Fisheries and Food Biotechnology. An Overview of Research Activities 1994-2002 - Programmes Fair and Biotech [FP4] Quality of Life Programme [FP5] 28,34). By the end of the decade, EU legislation had classified non-human animals as sentient.

Since the 1990s, sellfare has expanded rapidly and left its mark on a wide spectrum of phenomena. Numerous product labels and brand strategies have integrated welfare components (Schmid and Kilchsperger). A voluminous academic and report literature on welfare markets and supply chains has emerged (Miele and Lever; Brook Lyndhurst Ltd.; Gracia, Loureiro, and Nayga), a substantial portion of it directly or indirectly driven by state actors. Operational welfare measurement and certification systems have been developed, the most prominent of these being the massive 14-million-euro EU project Welfare Quality ${ }^{\circledR}$ (Blokhuis) that is now in the process of being adopted by many private and government initiatives. The demand, supply, and "transparency" of sellfare have been supported by education aimed at the regulators, assessors, 
consumers, and producers of welfare (Schmid and Kilchsperger; Kilchsperger, Schmid, and Hecht; Evans et al.). Celebrity chefs have allied with non-governmental organizations for "high welfare and a fair deal" (Compassion in World Farming). Trained welfare assessors have begun touring production facilities in order to link marketable welfare claims with production practices and animal indicators (Roe, Buller, and Bull). Efforts at international standardization have been made, sometimes with the explicit purpose of facilitating welfare trade (Thiernmann and Babcock). Private, thirdsector, and state bureaucracies have begun cultivating commodified welfare and addressing the manifold practical difficulties that derive from the abstraction and rationalization characteristic of it.

Despite its consolidation, sellfare is far from stable and universal. There is substantial variation among regulations, proficiencies, attitudes, and interpretations everywhere within sellfare (Kjaernes, Miele, and Roex; Spoolder et al.), all of which must be mitigated to some degree as welfare is abstracted into a freely exchangeable commodity. For example, Norwegian empty nesters in Welfare Quality ${ }^{\circledR}$ focus groups didn't trust product labels (Evans and Miele 85). They also felt that welfare should be state- rather than market-regulated, that they did not know enough to arbitrate on welfare, and that the killing of welfare animals remains problematic. Comparable moments of cognitive dissonance are undoubtedly still the norm rather than the exception within sellfare. Expert certification and education are needed to set minds at ease. Even with such efforts, however, consumers' willingness to pay for welfare products remains rather limited. Although potential and actual welfare premiums (Gracia, Loureiro, and Nayga; Norwood and Lusk 258-352) or market shares (Schulze) may in some cases reach tens of percentage points, they are still low enough that some aspects of welfare production remain hard-pressed to meet all consumers' intuitive understandings of "welfare."

Miele and Lever have argued that sellfare may, despite its failings, improve the welfare of livestock by drawing attention towards it and by preparing ground for future progress (Miele and Lever). The same process, however, also has a reverse side: sellfare is not only promoting welfare, but also adjusting it. Welfare Quality ${ }^{\circledR}$, for example, consulted citizens and experts for a definition of welfare. The resultant definition would have ranked half of European livestock production units as "unacceptable," so it was watered down in the final solution (Miele et al. 115). Other cases in point include the welfare gas and electrocution chambers of the industry-funded WelFur system (Mononen et al. 368) and the Freedom Food system's welfare CCTV cameras for slaughterhouse laborers (Royal Society for the Prevention of Cruelty to Animals). It is

Humanimalia: a journal of human/animal interface studies

Volume 7, Number 1 (Fall 2015) 
hardly surprising, then, that before economists can conduct willingness-to-pay experiments on welfare products, they must correct their subjects' understandings of what welfare means in the context of the livestock industry (Norwood and Lusk 258352). Commodified welfare is differentiating itself from non-commodified welfare, and adjusting the latter in the process.

In addition to redefining welfare, sellfare also relocates the welfare question from the sphere of the citizen to that of the consumer. Consumers are now "voting every day in favor of products that have implemented these animal welfare standards," as exCommissioner John Dalli proclaims in a video of the EU's welfare campaign, "Everyone is Responsible" (DG Health and Consumers). The contradiction between citizen and consumer is, however, difficult to paper over. By way of example: people prefer and vote for laws that prohibit whole classes of animal products, producing public rather than private goods (Norwood and Lusk 342). They bid differently in public-good welfare auctions than in product auctions (258-352). They express greater welfare interest in surveys (European Commission, Attitudes of EU Citizens towards Animal Welfare) than at supermarket counters. The consumer-citizen is a beast riven by a contradiction that cannot be dissolved by re-education. Some people will, furthermore, refuse both interpellations. This is why coercive apparatuses such as Europol's antiterrorists (Europol, TE-SAT 2011. EU Terrorism Situation and Trend Report 2011 22) or the public-private "Joint Forces Against Violent Animal Rights Extremists" (Europol, "Joint Forces against Violent Animal Rights Extremists") must stand ready.

Conclusions. As has been shown above, sellfare inherits four contradictions from earlier historical configurations and gives rise to a fifth. The first contradiction, between sensitivity and instrumentality, has plagued the human-non-human animal boundary since the emergence of the animal connection. This contradiction has frequently given rise to fare, i.e. human concern for non-human animal thriving. It was only in the 18th and 19th centuries, however, that fare came to be manipulated through the mediatized state-civil society dialectic of liberal fare governance. This gave rise to the ongoing contradiction between subjectivized animals as a means and object of liberal fare governance.

After the Second World War, livestock factories exacerbated the contradiction inherent in animal commodities. Public spectacle followed, and states responded with scientific livestock welfare governance. Governance helped steer welfare science in a policydriven and factory-centric direction. In the 1990s, scientifically-measured welfare 
entwined with agricultural quality, consolidating livestock welfare commodification as governance and internalizing a contradiction between consumer and citizen at the heart of sellfare.

Although sellfare is a continuation of several long historical processes, it differs from older modes of governance that do not encourage the production of welfare for sale. It subjects livestock welfare directly to competition and compels producers to manufacture welfare as cheaply as possible. Sellfare thus encourages the reduction of welfare into its commodity aspect, repeating the process that is at the root of welfare problems in the first place. Unlike protectionist governance, sellfare also confronts livestock suffering as a resource rather than as a problem. As Ryan Gunderson puts it in his critique of ethical food, "the very same mechanisms that cause capitalism's discontents are marketed as their own remedy" ("Problems with the Defetishization Thesis" 6). Finally, sellfare shifts the responsibility for livestock suffering from states and producers to consumers. This shift is part of a broader development in food governance that Julie Guthman (264) calls a "neoliberal anti-politics that devolves regulatory responsibility to consumers via their dietary choices."

Sellfare is not static, however. Its constituent parts are constantly in flux. If, for example, recent desensitization technologies such as in vitro [outside the living body] meat and the reduction of livestock sentience through genetic manipulation prove viable (cf. Shriver), sentient livestock may become obsolete. This would likely dissolve the contradiction of sensitivity and instrumentality that sellfare depends on. Desensitization has, however, proven vulnerable to public scandal around "frankenmeat" (Boyle and News) in ways that sellfare has not. The irony becomes palpable when one recalls WelFur's electrocution chambers.

Even if consumers find sellfare preferable to desensitization, the skeletons in sellfare's closet are haunting enough that resistance is to be expected. Policy-driven welfare science is particularly open to accusations of treating livestock as a means rather than an object. Criticism does not, however, necessarily challenge sellfare or its aspects. As Slavoj Žižek points out, subjects need not believe or accept a notion for it to function; they only need to act according to it (The Sublime Object of Ideology 28-30). Even if the imperfections of welfare production were suddenly widely recognized, consumers might be inclined to blame themselves and demand more expensive welfare products rather than question sellfare as such.

Humanimalia: a journal of human/animal interface studies

Volume 7, Number 1 (Fall 2015) 
One possible form of resistance to sellfare's responsibilization of consumers is to reemphasize the citizen aspect of welfare governance and call for a return to legislation over commodification. This answer would be in line with the cries for global Keynesian democracy (Patomäki) and emancipatory protectionism (Fraser, "A Triple Movement?") that have become fashionable of late. Although protectionism is unlikely to dissolve sellfare's contradictions, it may improve the prospects for governing some of them. Empowered governments could, for instance, more effectively steer consumption away from animal products by combining welfare measurement with other policy tools (cf. Vinnari and Tapio). This theme cannot be fully pursued here, but a thorough discussion of protectionism and sellfare is worthy of future inquiry.

Whatever path sellfare takes, one thing is certain: sellfare's complete undoing is unlikely. The technology for rendering welfare interchangeable with other abstract measurables will not go away. New vistas for both centralized and dispersed coordination are open, for good or for ill. Value and other forms of power now flow through sentient beings in ways that were previously inconceivable. Consider, for example, the recent interest in measuring and governing human well-being (Davies). When read together with sellfare, this gives rise to as-yet unexplored possibilities of human welfare commodification. Here, too, the application of power trumps its abolition.

\section{Works Cited}

Adams, Benjamin, and Jean Larson. "Legislative History of the Animal Welfare Act." USDA National Agricultural Library - Animal Welfare Information Center. N.p., 2012. 5 Aug. 2013.

http://www.nal.usda.gov/awic/pubs/AWA2007/intro.shtml.

Adams, Ronald J. "Fast Food and Animal Rights: An Examination and Assessment of the Industry's Response to Social Pressure." Business and Society Review 113.3 (2008): 301-328.

Althusser, Louis. For Marx. London: Verso, 2005.

Alvensleben, Reimar v. "Lebensmittelskandale Und Ökoprodukte - Wie Verbraucher Qualität Und Risiken Wahrnehmen.” Lohmann Information 4 (2002): n. pag. 1 Nov. 2013.

http://www.lohmann-information.com/content/1 i 402 artikel5.pdf 
American Pet Products Association. "Industry Statistics \& Trends." N.p., 2012. 11 Oct. 2012. http://www.americanpetproducts.org/press industrytrends.asp

Marketed in the EU Member States." 2010.

http://ec.europa.eu/agriculture/quality/certification/inventory/inventory-dataaggregations en.pdf

Barnett, Clive et al. "Consuming Ethics: Articulating the Subjects and Spaces of Ethical Consumption." Antipode 37.1 (2005): 23-45.

Barnosky, A. D. "Assessing the Causes of Late Pleistocene Extinctions on the Continents." Science 306.5693 (2004): 70-75.

Bateman, Connie Rae, John Paul Fraedrich, and Rajesh Iyer. "Framing Effects Within the Ethical Decision Making Process of Consumers." Journal of Business Ethics 36.1-2 (2002): 119-140.

Bennett, R.M. “Farm Animal Welfare and Food Policy." Food Policy 22.4 (1997): 281288.

Bentham, Jeremy. "To the Editor of the Morning Chronicle." Morning Chronicle 9 Mar. $1825: 2$.

Bevir, Mark. A Theory of Governance. Berkeley: U California P, 2013.

Bieleman, Jan. Five Centuries of Farming: A Short History of Dutch Agriculture, 1500-2000. Wageningen: Wageningen Academic Publishers, 2010.

Blackshaw, J.K. “Objective Measures of Welfare in Farming Environments.” Australian Veterinary Journal 63.11 (1986): 361-364.

Blokhuis, H J et al. "Measuring and Monitoring Animal Welfare: Transparency in the Food Product Quality Chain." Animal Welfare 12.4 (2003): 445-455.

Blokhuis, H.J. Improving Farm Animal Welfare: Science and Society Working Together: The Welfare Quality Approach. Wageningen: Wageningen Academic Publishers, 2013.

Humanimalia: a journal of human/animal interface studies

Volume 7, Number 1 (Fall 2015) 
Boyle, Alan, and Science Editor NBC News. "It's (not) Alive! Franken-Meat Lurches from the Lab to the Frying Pan - NBC News.com." NBC News. N.p., 4 Aug. 2013. 23 Jan. 2014.

http://www.nbcnews.com/technology/its-not-alive-franken-meat-lurches-lab-fryingpan-6C10835458

Brambell (chairman), F.W.R. Report of the Technical Committee to Enquire into the Welfare of Animals Kept under Intensive Husbandry Conditions. London: Her Majesty's Stationery Office, 1965.

Brantz, Dorothee. "The Domestication of Empire." A Cultural History of Animals in the Age of Empire. Ed. Kathleen Kete. London: Berg, 2011. 73-93.

Bromander, Lennart. "The Vivisection Debate in Sweden in the 1880s." Vivisection in Historical Perspective. Ed. Nicolaas A. Rupke. London: Taylor \& Francis, 1990. 214-236.

Brook Lyndhurst Ltd. Are Labels the Answer? Barriers to Buying Higher Animal Welfare Products. A Report for Defra. London: N.p., 2010.

http://randd.defra.gov.uk/Document.aspx?Document=CI0102Animal welfare final rep ort.pdf

Broom, D. M. "Animal Welfare: Concepts and Measurement." Journal of Animal Science 69 (1991): 4167-4175.

. "A History of Animal Welfare Science." Acta biotheoretica 59.2 (2011): 121-137.

Bryant, Edwin. "Strategies of Vedic Subversion - The Emergence of Vegetarianism in Post-Vedic India." A Communion of Subjects: Animals in Religion, Science, And Ethics. Ed. Paul Waldau. New York: Columbia UP, 2006. 194-203.

Budiansky, Stephen. The Covenant of the Wild. Why Animals Chose Domestication. New Haven and London: Yale UP, 1992.

Buller, H., and E. Roe. “Commodifying Animal Welfare." Animal Welfare 21 (2012): 131135.

\footnotetext{
Sami Torssonen - "Sellfare: A History of Livestock Welfare Commodification as Governance"
} 
Buller, Henry, and Christine Cesar. "Eating Well, Eating Fare: Farm Animal Welfare in France." International Journal of Sociology of Agriculture and Food 15.3 (2007): 45-58.

Burkhardt, Richard W. Patterns of Behavior: Konrad Lorenz, Niko Tinbergen, and the Founding of Ethology. Chicago: U Chicago P, 2005.

Carson, Rachel. Silent Spring. Boston: Mariner Books/Houghton Mifflin, 2012.

Clutton-Brock, Juliet. "How Domestic Animals Have Shaped the Development of Human Societies." A Cultural History of Animals in Antiquity. Vol. 1. Oxford: Berg, 2007.

Cole, Matthew. "From 'Animal Machines' to 'Happy Meat?' Foucault's Ideas of Disciplinary and Pastoral Power Applied to 'Animal-Centred' Welfare Discourse." Animals 1.1 (2011): 83-101.

Commission of the European Communities. COM (85) 333 Final, Perspectives for the Common Agricultural Policy (Communication of the Commission to the Council and the Parliament). Brussels: N.p., 1985. 23 Oct. 2013.

http://ec.europa.eu/greenpapers/pdf/green paper perspectives for cap com 85 333.pdf

. Coordinated Agricultural Research - A Record of Achievements. Luxembourg: Office for Official Publications of the European Communities, 1986.

Compassion in World Farming. "Chicken Out! Campaign for a Free Range Future." N.p., 2013. 9 Jan. 2014. http://www.chickenout.tv/

Cordain, L. "Implications of Plio-Pleistocene Hominin Diets for Modern Humans." Early Hominin Diets: The Known, the Unknown, and the Unknowable. Ed. P. Ungar. Oxford: Oxford UP, 2007. 363-383.

Council of Europe Publishing. Ethical Eye - Animal Welfare. Strasbourg: N.p., 2006.

Cronon, William. Nature's Metropolis: Chicago and the Great West. New York: W.W. Norton, 1991.

Crossley, Ceri. Consumable Metaphors: Attitudes Towards Animals and Vegetarianism in Nineteenth-Century France. Peter Lang, 2005.

Humanimalia: a journal of human/animal interface studies

Volume 7, Number 1 (Fall 2015) 
Cunningham, D. L. "Beak Trimming Effects on Performance, Behavior and Welfare of Chickens: A Review." The Journal of Applied Poultry Research 1.1 (1992): 129-134.

Darwin, Charles. The Expression of the Emotions in Man and Animals. London: John Murray, 1872. 7 May 2013.

Davies, William. "The Political Economy of Unhappiness." New Left Review 71 (2011): 65-80. II.

Dawkins, Marian Stamp. Animal Suffering: The Science of Animal Welfare. London; New York: Chapman and Hall, 1980.

Deleuze, Gilles, and Félix Guattari. A Thousand Plateaus: Capitalism and Schizophrenia. Minneapolis: U Minnesota P, 1987.

DG Health and Consumers. EUROPA - Animal Health \& Welfare - Animal Welfare Everyone Is Responsible - Video. 03:55-04:07: N.p., n.d. Film.

Domínguez-Rodrigo, Manuel, Travis Rayne Pickering, and Henry T. Bunn. "Reply to McPherron et Al.: Doubting Dikika Is about Data, Not Paradigms." Proceedings of the National Academy of Sciences 108.21 (2011): E117-E117.

Duncan, I.J.H., and D.G.M. Wood-Gush. "Frustration and Aggression in the Domestic Fowl." Animal Behaviour 19.3 (1971): 500-504.

Eriksson, Kai, and Henri Vogt. "On Self-Service Democracy Configurations of Individualizing Governance and Self-Directed Citizenship." European Journal of Social Theory 16.2 (2013): 153-173.

EU Enforcement Network for Animal Welfare Lawyers and Commissioners. “National Animal Welfare Legislation." N.p., n.d. 9 Jan. 2014.

http://lawyersforanimalprotection.eu/ national-animal-welfare-legislation

European Commission. "Animal Welfare - International Conference on the EU Animal Welfare Strategy." N.p., 2012. 14 Nov. 2012.

http://ec.europa.eu/dgs/health consumer/dyna/enews/enews.cfm?al id=1212

Sami Torssonen - "Sellfare: A History of Livestock Welfare Commodification as Governance" 
. Attitudes of EU Citizens towards Animal Welfare. N.p., 2007. 15 June 2012. http://ec.europa.eu/public opinion/archives/ebs/ebs 270 en.pdf

. "Communication From the Commission to the European Parliament, the Council and the European Social Committee on the European Union Strategy for the Protection and Welfare of Animals 2012-2015." N.p., 2012. 26 Apr. 2012. http://eur-lex.europa.eu/legal-content/EN/TXT/?uri=celex:52012AE1305

. "Ethical, Legal and Socio-Economic Aspects of Agriculture, Fisheries and Food Biotechnology. An Overview of Research Activities 1994-2002 - Programmes Fair and Biotech (FP4) Quality of Life Programme (FP5)." Ed. S. Caro. Directorate-General for Research, 2002.

https://ec.europa.eu/research/biosociety/pdf/agrofood.pdf

Europol. "Joint Forces against Violent Animal Rights Extremists." N.p., 2011. 30 May 2012.

https://www.europol.europa.eu/content/press/joint-forces-against-violent-animalrights-extremists-1023

2012.

. TE-SAT 2011. EU Terrorism Situation and Trend Report 2011. N.p., 2011. 29 June https://www.europol.europa.eu/sites/default/files/publications/te-sat2011.pdf

Evans, Adrian et al. The Provision of Educational Materials about Farmed Animal Welfare: A Comparative Report. Welfare Quality Reports, 2010.

http://www.welfarequality.net/everyone/44898/7/0/22

Evans, Adrian, and Mara Miele. Consumers' Views about Farm Animal Welfare Part II: European Comparative Report Based on Focus Group Research. Welfare Quality Reports, 2008.

http://www.cardiff.ac.uk/cplan/sites/default/files/WQReport-5 0.pdf

Fanatico, Anne, Holly Born, and Betsy Conner. "Label Rouge: Pasture-Based Poultry Production in France." Attra 2010. 13 Dec. 2013.

https://attra.ncat.org/attra-pub/summaries/summary.php?pub=224

Humanimalia: a journal of human/animal interface studies

Volume 7, Number 1 (Fall 2015) 
Favre, David, and Vivien Tsang. "The Development of Anti-Cruelty Laws During the 1800s." Detroit College of Law Review 1.1 (1993): n. pag. 7 May 2013.

http://digitalcommons.law.msu.edu/cgi/viewcontent.cgi?article=1146\&context=facpubs

Federico, Giovanni. Feeding the World: An Economic History of Agriculture, 1800-2000. Princeton: Princeton UP, 2005.

Fitzgerald, Amy J. "A Social History of the Slaughterhouse: From Inception to Contemporary Implications." Research in Human Ecology 17.1 (2010): 58-69.

Fitzgerald, Deborah. Every Farm a Factory: The Industrial Ideal in American Agriculture. New Haven: Yale UP, 2010.

Fraser, Nancy. "Rethinking the Public Sphere: A Contribution to the Critique of Actually Existing Democracy." Social Text 25/26 (1990): 56-80.

_. "A Triple Movement?” New Left Review 81 (2013): 119-132. II.

Franklin, Adrian. Animals and Modern Cultures: A Sociology of Human-Animal Relations in Modernity. London: Sage, 1999.

Freidberg, Susanne. "The Ethical Complex of Corporate Food Power." Environment and Planning D: Society and Space 22.4 (2004): 513-531.

Friedmann, Erika, and Heesook Son. "The Human-Companion Animal Bond: How Humans Benefit." The Veterinary clinics of North America. Small animal practice 39.2 (2009): 293-326.

Gepts, Paul et al., eds. Biodiversity in Agriculture: Domestication, Evolution, and Sustainability. New York: Cambridge UP, 2012.

Gracia, Azucena, Maria L Loureiro, and Jr. Nayga. "Valuing an EU Animal Welfare Label Using Experimental Auctions." Agricultural Economics 00 (2011): 1-9.

Gray, Philip Howard. "Spalding and His Influence on Research in Developmental Behavior." Journal of the History of the Behavioral Sciences 3.2 (1967): 168-179.

\footnotetext{
Sami Torssonen - "Sellfare: A History of Livestock Welfare Commodification as Governance"
} 
Guither, Harold D. Animal Rights: History and Scope of a Radical Social Movement. Carbondale: Southern Illinois UP, 1998.

Gunderson, Ryan. "From Cattle to Capital: Exchange Value, Animal Commodification, and Barbarism." Critical Sociology 39.2 (2011): 259-275.

- "Problems with the Defetishization Thesis: Ethical Consumerism, Alternative Food Systems, and Commodity Fetishism." Agriculture and Human Values (2013): 1-9.

Guthman, Julie. "Commentary on Teaching Food: Why I Am Fed up with Michael Pollan et al." Agriculture and Human Values 24.2 (2007): 261-264.

Habermas, Jürgen. The Structural Transformation of the Public Sphere: An Inquiry into a Category of Bourgeois Society. Cambridge, MA: The MIT Press, 1991.

Hardouin-Fugier, Elisabeth. "From Animal Suffering to Animal Welfare: The Progressive Attainment of Animal Rights in Europe." Ethical Eye - Animal Welfare. Council of Europe Publishing, 2006. 171-184.

Harrison, Ruth, Rachel Carson, and Marian Stamp Dawkins. Animal Machines. Boston: CABI, 2013.

Harvey, David. A Brief History of Neoliberalism. First Edition. New York: Oxford UP, 2005.

Harvey, David, and Carmen Hubbard. "Reconsidering the Political Economy of Farm Animal Welfare: An Anatomy of Market Failure." Food Policy 38 (2013): 105-114.

Haskell, Thomas L. "Capitalism and the Origins of the Humanitarian Sensibility, Part 1." The American Historical Review 90.2 (1985): 339-361.

- "Capitalism and the Origins of the Humanitarian Sensibility, Part 2." The American Historical Review 90.3 (1985): 547-566.

Haynes, Richard P., ed. Animal Welfare. Competing Conceptions and Their Ethical Implications. Dordrecht: Springer Netherlands, 2008.

Humanimalia: a journal of human/animal interface studies

Volume 7, Number 1 (Fall 2015) 
Helvenston, Patricia A., and Derek Hodgson. "Wild Thing, I Think I Love You." Current Anthropology 52.3 (2011): 433-433.

Hemsworth, Paul, and Grahame Coleman. Human-Livestock Interactions: The Stockperson and the Productivity and Welfare of Intensively Farmed Animals. Wallingford, UK; Cambridge, MA: CAB International, 2011.

Hobbs, A. L. et al. "Ethics, Domestic Food Policy and Trade Law: Assessing the EU Animal Welfare Proposal to the WTO." Food Policy 27.5-6 (2002): 437-454.

Hodgson, Derek, and Patricia A. Helvenston. "The Emergence of the Representation of Animals in Palaeoart: Insights from Evolution and the Cognitive, Limbic and Visual Systems of the Human Brain." Rock Art Research 23.1 (2006): 3-39.

Horowitz, Roger. Putting Meat on the American Table: Taste, Technology, Transformation. Baltimore: The Johns Hopkins UP, 2006.

Hribal, Jason. "Animals Are Part of the Working Class': A Challenge to Labor History." Labor History 44.4 (2003): 435-453.

Huylenbroeck, Guido van, and Guy Durand. Multifunctional Agriculture: A New Paradigm for European Agriculture and Rural Development. Aldershot: Ashgate Publishing, 2003.

Ingenbleek, Paul T.M. et al. "EU Animal Welfare Policy: Developing a Comprehensive Policy Framework." Food Policy 37.6 (2012): 690-699.

Ingenbleek, Paul T.M., et al. "A Scenario Analysis on the Implementation of a Farm Animal Welfare Assessment System." Animal Welfare 20 (2011): 613-621.

Kalof, Linda. "Introduction - Ancient Animals." A Cultural History of Animals in Antiquity. Vol. 1. Oxford: Berg Publishers, 2007.

Kean, Hilda. "The 'Smooth Cool Men of Science': The Feminist and Socialist Response to Vivisection." History Workshop Journal 40.1 (1995): 16-38. 
Kelch, Thomas G. “A Short History of (Mostly) Western Animal Law: Part 1." Animal Law 19 (2012): 23-185.

. "A Short History of (Mostly) Western Animal Law: Part II." Animal Law 19 (2013): 347-497.

Kelemen, Mihaela. “Too Much or Too Little Ambiguity: The Language of Total Quality Management." Journal of Management Studies 37.4 (2000): 483-498.

Kete, Kathleen. "Animals and Human Empire." A Cultural History of Animals in the Age of Empire. Ed. Kathleen Kete. London: Bloomsbury Academic, 2011. 1-24.

. The Beast in the Boudoir: Petkeeping in Nineteenth-Century Paris. Berkeley: U California P, 1994.

Kilchsperger, Rahel, Otto Schmid, and Judith Hecht. Animal Welfare Initiatives in Europe - Technical Report on Grouping Method for Animal Welfare Standards and Initiatives. Deliverable No. 1.1 of EconWelfare Project. Frick, Switzerland: Research Institute of Organic Agriculture FiBL, 2010. 9 Jan. 2014.

http://www.econwelfare.eu/publications/EconWelfareD1.1-final updateOct2010.pdf

Kirk, Robert G.W. "The Invention of the 'Stressed Animal' and the Development of a Science of Animal Welfare, 1948-1986." Stress, Shock, and Adaptation in the Twentieth Century. Eds., David Cantor and David Ramsden. Rochester: U Rochester P, 2014. 241259.

Kjaernes, Unni, Mara Miele, and Joek Roex. Attitudes of Consumers, Retailers and Producers to Farm Animal Welfare. Welfare Quality Reports, 2007. 18 September 2015. http://www.cardiff.ac.uk/cplan/sites/default/files/WQReport-2 0.pdf

Lansbury, Coral. The Old Brown Dog: Women, Workers, and Vivisection in Edwardian England. Madison, Wis.: U Wisconsin P, 1985.

Larson, Greger et al. "Rethinking Dog Domestication by Integrating Genetics, Archeology, and Biogeography." Proceedings of the National Academy of Sciences (2012): n. pag. 9 Oct. 2012.

http://www.pnas.org/content/109/23/8878.full.pdf\#page=1\&view=FitH

Humanimalia: a journal of human/animal interface studies

Volume 7, Number 1 (Fall 2015) 
Lawrence, Alistair B. "Applied Animal Behaviour Science: Past, Present and Future Prospects." Applied Animal Behaviour Science 115.1-2 (2008): 1-24.

Lee, Patrick C. "The Human Child's Nature Orientation." Child Development Perspectives 6.2 (2012): 193-198.

Lee, Paula Young, ed. Meat, Modernism, and the Rise of the Slaughterhouse. Durham: U New Hampshire P, 2008.

Legge, Debbie, and Simon Brooman. Law Relating To Animals. London: Cavendish, 1997.

Li, Chien-Hui. "A Union of Christianity, Humanity, and Philanthropy: The Christian Tradition and the Prevention of Cruelty to Animals in Nineteenth-Century England." Society and Animals 8.3 (2000): 265-285.

Malcolmson, Robert, and Stephanos Mastoris. The English Pig: A History. London: Hambledon Continuum, 1998.

Marx, Karl. Capital. A Critique of Political Economy. Volume One. Trans. Ben Fowkes. London: Penguin, 1976.

Marx, Karl. Grundrisse: Foundations of the Critique of Political Economy. Trans. Martin Nicolaus. London: Penguin, 1993.

Mason, Jim. "Animals - From Souls and the Sacred in Prehistoric Times to Symbols and Slaves in Antiquity." A Cultural History of Animals in Antiquity. Vol. 1. Ed., Linda Kalof. Oxford: Berg, 2007. 17-45.

Miele, M. et al. "Animal Welfare: Establishing a Dialogue between Science and Society." Animal Welfare 20.1 (2011): 103-117.

Miele, Mara, and John Lever. "Civilizing the Market for Welfare Friendly Products in Europe? The Techno-Ethics of the Welfare Quality ${ }^{\circledR}$ Assessment." Geoforum 48 (2013): 63-72.

Mithen, Steven. The Prehistory Of The Mind: A Search for the Origins of Art, Religion and Science. London: Orion, 1998.

Sami Torssonen - "Sellfare: A History of Livestock Welfare Commodification as Governance" 
Mononen, J et al. "The Development of on-Farm Welfare Assessment Protocols for Foxes and Mink: The WelFur Project." Animal Welfare 21.3 (2012): 363-371.

Neuland. “Die Geschichte Des NEULAND-Vereins.” N.p., n.d. 17 Dec. 2013. http://www.neuland-fleisch.de/verein/geschichte.html

Norwood, F. Bailey, and Jayson L. Lusk. Compassion, by the Pound: The Economics of Farm Animal Welfare. New York: Oxford UP, 2011.

O'Brien, Michael J., and Kevin N. Laland. "Genes, Culture, and Agriculture." Current Anthropology 53.4 (2012): 434-470.

Overbeek, Henk. Global Governance, Class, Hegemony: A Historical Materialist Perspective. Amsterdam: Vrije Universiteit, Department of Political Science, 2004. 6 June 2014.

Page, Brian, and Richard Walker. "From Settlement to Fordism: The Agro-Industrial Revolution in the American Midwest." Economic Geography 67.4 (1991): 281-315.

Patomäki, Heikki. The Great Eurozone Disaster. From Crisis to Global New Deal. First edition. London; New York: Zed Books, 2013.

Petersen, Klaus, and Jørn Henrik Petersen. "Confusion and Divergence: Origins and Meanings of the Term 'welfare State' in Germany and Britain, 1840-1940." Journal of European Social Policy 23.1 (2013): 37-51.

Philo, Chris. "Animals, Geography, and the City: Notes on Inclusions and Exclusions." Environment and Planning D: Society and Space 13.6 (1995): 655-681.

Polanyi, Karl. The Great Transformation: The Political and Economic Origins of Our Time. 2nd ed. Boston: Beacon Press, 2001.

Potter, Clive, and Mark Tilzey. "Agricultural Policy Discourses in the European PostFordist Transition: Neoliberalism, Neomercantilism and Multifunctionality." Progress in Human Geography 29.5 (2005): 581-600.

Preece, Rod, ed. Awe for the Tiger, Love for the Lamb: A Chronicle of Sensibility to Animals. Routledge. New York, London: UBC Press, 2002.

Humanimalia: a journal of human/animal interface studies

Volume 7, Number 1 (Fall 2015) 
Ritvo, Harriet. The Animal Estate: The English and Other Creatures in the Victorian England. Cambridge: Harvard UP, 1987.

Röcklinsberg, Helena, and Per Sandin, eds. The Ethics of Consumption: The Citizen, the Market, and the Law. Wageningen: Wageningen Academic Publishers, 2013.

Roe, E., H. Buller, and J. Bull. "The Performance of Farm Animal Assessment." Animal Welfare 20.1 (2011): 69-78.

Rollin, Bernard E. "Scientific Ideology, Anthropomorphism, Anecdote, and Ethics." New Ideas in Psychology 18.1 (2000): 109-118.

Royal Society for the Prevention of Cruelty to Animals. "RSPCA Welfare Standards for Farm Animals - New Standards and Guidance Requiring the Installation of CCTV in Abattoirs (mammals)." 2011. 10 Jan. 2014.

http://www.fao.org/fileadmin/user upload/animalwelfare/RSPCA welfare standards f or pigs 2010.pdf

Runge, C. Ford. "Agricultural Economics: A Brief Intellectual History." Center for International Food and Agricultural Policy Working Paper (2006): n. pag. 21 Aug. 2013.

http://ageconsearch.umn.edu/bitstream/13649/1/wp06-01.pdf

Sandilands, V. "David Wood-Gush The Biography of an Ethology Mentor." Applied Animal Behaviour Science 87.3-4 (2004): 173-176.

Schaefer, Anja, and A. Crane. "Rethinking Green Consumption." Globalisation and Equity: Proceedings of the 26th Annual Macromarketing Conference. Ed. Don R. Rahtz, Pierre McDonagh, and D. Bouchet. Williamsburg, USA: The College of William and Mary, 2001. 178-195. 8 Nov. 2013.

http://oro.open.ac.uk/1956/

Schmid, Otto, and Rahel Kilchsperger. Overview of Animal Welfare Standards and Initiatives in Selected EU and Third Countries. Frick, Switzerland: Research Institute of Organic Agriculture (FiBL), 2010. 15 June 2012. http://www.econwelfare.eu/publications/EconWelfareD1.2Report update Nov2010.pdf

\footnotetext{
Sami Torssonen - "Sellfare: A History of Livestock Welfare Commodification as Governance"
} 
Schulze, Birgit, Achim Spiller, and Daniela Lemke. "Glücksschwein oder arme Sau? Die Einstellung der Verbraucher zur modernen Nutztierhaltung." Zukunftsperspektiven der Fleischwirtschaft - Verbraucher, Märkte, Geschäftsbeziehungen. Eds. Achim Spiller and Birgit Schulze. Göttingen: Universitetsverlag Göttingen, 2008. 465-488.

Seidman, Steven. "Beyond Presentism and Historicism: Understanding the History of Social Science." Sociological Inquiry 53.1 (1983): 79-91.

Shaw, Deirdre, Terry Newholm, and Roger Dickinson. "Consumption as Voting: An Exploration of Consumer Empowerment." European Journal of Marketing 40.9/10 (2006): 1049-1067.

Shipman, Pat. "The Animal Connection and Human Evolution." Current Anthropology 51.4 (2010): 1-21.

. The Animal Connection: A New Perspective on What Makes Us Human. New York: W. W. Norton \& Company, 2011.

Shriver, Adam. "Knocking Out Pain in Livestock: Can Technology Succeed Where Morality Has Stalled?" Neuroethics 2.3 (2009): 115-124.

Smith, Bradley Philip, and Carla Anita Litchfield. "How Well Do Dingoes, Canis Dingo, Perform on the Detour Task?" Animal Behaviour 80.1 (2010): 155-162.

Spoolder, Hans et al. EconWelfare Findings, Conclusions and Recommendations Concerning Effective Policy Instruments in the Route towards Higher Animal Welfare in the EU. N.p., 2011.

http://www.econwelfare.eu/publications/EconWelfareD0.5 Findings conclusions and recommendations.pdf

Steinfeld, Henning et al. Livestock in a Changing Landscape, Volume 1: Drivers, Consequences, and Responses. Washington, D.C.: Island Press, 2010.

Stock-Morton, Phyllis. Moral Education for a Secular Society: The Development of Moral Laique in Nineteenth Century France. Albany: State U New York P, 1988.

Humanimalia: a journal of human/animal interface studies

Volume 7, Number 1 (Fall 2015) 
Stookey, J. M., and L. A. Goonewardene. "A Comparison of Production Traits and Welfare Implications between Horned and Polled Beef Bulls." Canadian Journal of Animal Science 76.1 (1996): 1-5.

Streeck, Wolfgang. "Citizens as Customers." New Left Review 76 (2012): 27-47. II.

Talebinejad, M. Reza, and H. Vahid Dastjerdi. "A Cross-Cultural Study of Animal Metaphors: When Owls Are Not Wise!" Metaphor and Symbol 20.2 (2005): 133-150.

Tester, Keith. Animals \& Society. The Humanity of Animal Rights. London: Routledge, 1991.

The Council of Europe. European Convention for the Protection of Animals during International Transport. N.p., 1968.

http://conventions.coe.int/Treaty/EN/Treaties/Html/193.htm

The Food and Agriculture Organization of the United Nations. "Animal Welfare: A Win-Win Opportunity for Animals, Farmers and Consumers." Gateway to Farm Animal Welfare. N.p., 29 Oct. 2012. 13 Nov. 2012.

http://www.fao.org/ag/againfo/themes/animal-welfare/news-detail/en/c/164058/

Thiernmann, A.B., and S. Babcock. "Animal Welfare and International Trade." Revue scientifique et techniquel Office international des épizooties 24.2 (2005): 747-755.

Thornton, Philip K. "Livestock Production: Recent Trends, Future Prospects." Philosophical Transactions of the Royal Society B: Biological Sciences 365.1554 (2010): 28532867.

Turner, E. S. All Heaven in a Rage. London: Open Gate Press, 1992.

Vinnari, Markus, and Petri Tapio. "Sustainability of Diets: From Concepts to Governance." Ecological Economics 74.0 (2012): 46-54.

Vitell, Scott J. "Consumer Ethics Research: Review, Synthesis and Suggestions for the Future." Journal of Business Ethics 43.1-2 (2003): 33-47. 
Vogel, David. Trading Up: Consumer and Environmental Regulation in a Global Economy. Cambridge, MA: Harvard UP, 1997.

White, John H. The Great Yellow Fleet: A History of American Railroad Refrigerator Cars. San Marino: Golden West Books, 1986.

Wilkinson, J. M., K. K. Bolsen, and C. J. Lin. "History of Silage." Silage Science and Technology. Eds. Dwayne R. Buxton, Richard E. Muck, and Joseph H. Harrison. Madison: American Society of Agronomy, 2003. 1-30.

Williams, Anna. "Disciplining Animals: Sentience, Production, and Critique." International Journal of Sociology and Social Policy 24.9 (2004): 45 - 57

Winter, M, C Fry, and S.P Carruthers. "European Agricultural Policy and Farm Animal Welfare." Food Policy 23.3-4 (1998): 305-323.

Woods, Abigail. "From Cruelty to Welfare: The Emergence of Farm Animal Welfare in Britain, 1964-71." Endeavour 36.1 (2012): 14-22.

. "Rethinking the History of Modern Agriculture: British Pig Production, c.191065." Twentieth Century British History 23.2 (2012): 165-191.

Zeder, Melinda A. "Pathways to Animal Domestication." Biodiversity in Agriculture: Domestication, Evolution, and Sustainability. Ed. Paul Gepts, et al. Cambridge: Cambridge UP, 2012. 227-259.

Zerbel, Miriam. Tierschutz im Kaiserreich: ein Beitrag zur Geschichte des Vereinswesens. Bern and Frankfurt am Main: Peter Lang, 1993.

Zeuner, Frederick. A History of Domesticated Animals. London: Hutchinson of London, 1963.

Žižek, Slavoj. First As Tragedy, Then As Farce. Verso, 2009.

. The Sublime Object of Ideology. London: Verso, 1989.

Humanimalia: a journal of human/animal interface studies

Volume 7, Number 1 (Fall 2015) 